Турканова В.І. Відкрите і гласне виконання судових рішень в Україні в світлі практики Європейського суду...

lete compliance of the grounds for exempting the carrier from liability, enshrined in national legislation and international legal acts, certain problems of application of legal norms defining civil liability of the railway carrier for loss of cargo.

Key words: rail transportation, cargo, loss of cargo, damages, railway carrier, civil liability of the railway carrier.

DOI: 10.36695/2219-5521.2.2019.44

удК 347.91

\title{
B.I. ТУРКАНОВА
}

Владислава Іеорівна Турканова, студентка магістратури юридичного фракультету Київського національного університету імені Тараса Шевченка*

ORCHID: 0000-0002-8345-6681

\section{ВІДКРИТЕ I ГЛАСНЕ ВИКОНАННЯ СУДОВИХ РІШЕНЬ В УКРАЇНІ В СВІТЛІ ПРАКТИКИ ЄВРОПЕЙСЬКОГО СУДУ 3 ПРАВ ЛЮДИНИ}

Постановка проблеми. Верховенство права та доступ до правосуддя є одними з основоположних прав людини, що гарантовані Загальною декларацією про права людини (далі - Загальна декларація) ${ }^{1}$ та Конвенцією про захист прав людини і основоположних свобод і протоколів до неї (далі - Свропейська конвенція) ${ }^{2}$. У практиці Свропейського суду з прав людини (далі - ЄСПЛ або Суд) напрацьовано низку елементів, що $є$ складовими права на справедливий судовий розгляд, зокрема в аспекті забезпечення публічності судового розгляду справи та проголошення судового рішення. Ця ідея прилюдного або відкритого і гласного судового розгляду, закріплена на рівні міжнародних актів, стала основою і гарантувала цілий комплекс прав людини, що в подальшому знайшли свою реалізацію в законодавстві провідних держав світу 3 .

Гласність і відкритість судового процесу є іманентними рисами правосуддя, забезпечуючи можливість залучення суспільства та відповідний рівень довіри до судової діяльності, які слугують гарантіями реалізації інших засад судочинства, таких, як рівноправність сторін та їх змагальність. Але захист прав здійснюється не тільки в ході розгляду справи судом - його невід'ємною складовою є виконання ухваленого судового рішення, що дає можливість реалізувати основну мету всієї цієї діяльності. Отже, гарантія відкритості та гласності виконання судового рішення теж має важливе значення.

Україна як член Організації Об’єднаних Націй (далі - ООН) та Ради Європи (далі - РЄ) упродовж усього періоду своєї незалежності докладає зусилля до наближення національного законодавства та судової практики до загальносвітових та європейських стандартів. Під час реформування системи правосуддя в України у відповідних процесуальних кодексах України було істотно оновлено положення про відкритість та гласність судових проваджень у справі ${ }^{4}$. Зокрема, в нових редакціях було уточнено положеннями про гласність судового розгляду та відкритість інформації про справу (наприклад, ст. 7 «Гласність судового процесу» та ст. 8 «Відкритість інформації щодо справи» Цивільного процесуального кодексу України (далі - ЦПК). Було також ухвалено новий Закон «Про виконавче провадження» ${ }^{5}$ (далі - Закон про виконання), ст. 2 якого було закріплено засади здійснення виконавчого провадження, серед яких гласність та відкритість здійснення виконавчого провадження в України. Водночас жодних конкретних положень, в яких розкривається сутність зазначеного принципу, у зазначеному законі немає.

Відкритість та гласність здійснення правосуддя у цивільних справах є доволі дослідженою темою у правовій науці, зокрема, у нашому дослідженні ми аналізували основні положення робіт К. Ван Реє, Дж. Йлловича, І.О. Ізарової, М. Каппеллетті, В.В. Комарова, В.А. Кройтора, Дж. Резнік, А. Узелаца, С.Я. Фурси, Дж. Хаззарда-мол., Р.Ю. Ханик-Посполітак, І.С. Ярошенко. Водночас питанням відкритості та гласності як принципу виконання судових рішень у науці приділено менше уваги, зокрема, в роботі О.С. Снідевича6.

Формулювання мети статті. Відсутність чіткого правового регулювання положень про вчинення конкретних процесуальних дій в ході виконання судових рішень $є$ актуальною проблемою, що призводить до проблем реалізації права особи на справедливий судовий розгляд під час здійснення виконавчого провадження. Водночас системно-структурний підхід до характеристики виконання як найважливішої частини правосуддя та процесу захисту прав, що забезпечує конкретні гарантії реалізації права на справедливий суд, дає можливість запропонувати шляхи їх вирішення. 3 огляду на зазначене, предметом свого дослідження ми обрали принцип відкритості та гласності виконавчого процесу, а у висновках пропонуємо комплексно удосконалити виконання судових рішень та наблизити до сучасної концепції здійснення правосуддя у справі шляхом трансформування цієї засади у гласність вчинення виконавчих дій та відкритість інформації щодо виконавчого провадження. 3 огляду на це, метою статті є визначення конкретних елементів реалізації принципу

(C) В.І. Турканова, 2019

*Vladyslava Turkanova, master student of the Law Faculty of Taras Shevchenko National University of Kyiv 
відкритості та гласності виконавчого процесу на основі аналізу законодавства України та інших держав світу, національної правової доктрини та судової практики Європейського суду з прав людини.

Виклад основного матеріалу. Відкритість та гласність правосуддя є важливими засадами, що визначе-

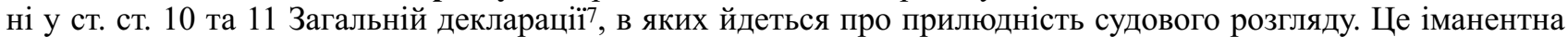
риса судочинства, яка кореспондується із засадами його публічності ${ }^{8}$. Прилюдність судового процесу, що полягає у можливості вільного доступу до судового засідання з розгляду справи для всіх заінтересованих осіб, можна розглядати як невід’ємний елемент концепції верховенства права'

Подальшого розвитку ця ідея знайшла в Європейській конвенції, яка, безумовно, є найважливішим дороговказом для нашої держави. Упродовж останніх десятиліть реалізації ії положень в практиці ЄСПЛ сформувалися основні елементи концепції права на справедливий судовий розгляд. Зокрема, у ст. 6 закріплено вимоги щодо публічного розгляду справи, а також публічного проголошення судового рішення ${ }^{10}$, що можна вважати ядром концепції права особи на справедливий суд. Відкритість та гласність здійснення правосуддя і захисту прав означає не тільки відкрите публічне судове засідання з розгляду справи і відкрите проголошення судового рішення, а й виконання судового рішення як фінальної заключної частини процесу захисту прав ${ }^{11} 3$ огляду на таке.

У своєму рішенні у справі Крутько проти України ${ }^{12}$ Суд зауважив, що провадження в суді та виконавче провадження є відповідно першою і другою стадіями одного провадження і не можуть бути відокремлені один від одного, оскільки вони мають розглядатися як цілісний процес захисту прав особи. Навіть більше, у рішенні у справі Шмалько проти України ЄСПЛ зазначив, що право на суд було б лише ілюзією, якщо б держави допускали такий стан речей, коли остаточні рішення національних судів залишалися б невиконаними; а тлумачення частини першої ст. 6 Конвенції винятково як такої, що стосується лише доступу до суду та процедури розгляду справи у суді, було б несумісним із принципом верховенства права, який держави-учасниці зобов'язались дотримувати, ратифікуючи Конвенцію ${ }^{13}$. Згідно 3 практикою ЄСПЛ до розумного строку розгляду справи включається період із моменту надходження до суду заяви і до моменту закінчення виконання рішення суду, про що зазначено в багатьох його рішеннях ${ }^{14}$.

Зважаючи на зазначену практику ЄСПЛ, в правовій доктрині виконання рішення будь-якого суду також розглядають у світлі вимог ст. 6 Конвенції як складову частину розгляду справи 15 . Навіть більше, у рекомендаціях РС зауважено, що справедливий, ефективний і доступний судоустрій зміцнює верховенство права, що лежить у підвалинах європейських демократій, а примусове виконання судового рішення є невід'ємною частиною основоположного права людини на справедливий судовий розгляд упродовж розумного часу, як це визначено в ст. 6 Конвенції 16 .

На наше переконання, виконання судових рішень відбувається в межах реалізаџї права кожного на справедливий суд, отже, має відповідати основним засадам здійснення судового розгляду у світлі реалізації положень Свропейської конвенції та практики ССПЛ, зокрема, у частині відкритості та гласності виконання судових рімень.

Відповідні положення зазначених вище рішень ССПЛ гарантують повну реалізачію права на справедливий суд крізь призму Свропейської конвениї та верховенства права як однієї з визначальних засад. Ураховуючи иче, національне законодавство України як члена РС та держсави, щзо ратифікувала Конвениію та протоколи до неї, також повинні рефлектувати відповідні норми, зокрема, й ті, щуо забезпечують публічність судового розгляду і їх виконання.

У Конституції України проголошено гласність судового процесу, закріплюючи їі на рівні основної засади судочинства у ст. 129 17. Ї̈ реалізація, в тому числі й за рахунок повного фіксування судового процесу технічними засобами, стали об'єктом судового розгляду в порядку конституційного судочинства у 2011 році18. У процесуальних кодексах передбачені загальні положення та певні особливості здійснення повного фіксування судового процесу технічними засобами (див. положення ч. 14 ст. 7, а також ст. ст. 43, 67, 203, 247-250 ЦПК ${ }^{19}$, ст. ст. 222-225 ГПК ${ }^{20}$ та ст. ст. 229-234 КАС $\left.{ }^{21}\right)$. Загальні вимоги щодо фіксування судового засідання технічними засобами, що містяться в процесуальних кодексах, є ідентичними. Водночас певні аспекти регулювання відкритості та гласності судового процесу передбачені в законодавстві про судоустрій і статус суддів, а інші - в процесуальному законодавстві різних видів судочинства.

У ст. 11 Закону України «Про судоустрій і статус суддів»22 зазначено, що гласність і відкритість судового процесу полягає насамперед у тому, що судові рішення, судові засідання та інформація щодо справ, які розглядаються судом, є відкритими і ніхто не може бути обмежений у праві на отримання в суді усної або письмової інформації про результати розгляду його судової справи. Навіть більше, якщо особа не брала участі в справі, але звернулася до суду із заявою про те, що ухвалене судове рішення зачіпає ії права та обов'язки, то згідно з частиною другою ст. 8 ЦПК мають право подати апеляційну чи касаційну скаргу на відповідне рішення і ознайомлюватися з матеріалами справи, робити 3 них витяги, знімати копії з документів, долучених до справи, одержувати копії судових рішень.

Слід визнати, що в Україні наразі діє безпрецедентна практика забезпечення будь-якій особі права на вільний доступ до всіх судових рішень, які відповідно до Закону України «Про доступ до судових рішень» ${ }^{23}$ публікуються у вільному доступі в Єдиному державному реєстрі судових рішень (далі - ЄДРСР) http://reyestr.court.gov.ua. Така ідея була реалізована з огляду на необхідність забезпечити доступ громадськості до актів судової влади, а також з метою унеможливлення будь-яких зловживань, зокрема, внесенням змін до вже проголошеного рішення суду ${ }^{24}$. 
Турканова В.І. Відкрите і гласне виконання судових рішень в Україні в світлі практики Європейського суду...

Згідно 3 ч. 2 ст. 2 зазначеного Закону усі судові рішення є відкритими та підлягають оприлюдненню в електронній формі не пізніше наступного дня після їх виготовлення і підписання. Для доступу до судових рішень судів загальної юрисдикції Державна судова адміністрація України забезпечує ведення ЄДРСР - це автоматизована система збирання, зберігання, захисту, обліку, пошуку та надання електронних копій судових рішень (ч. ч. 1 та 2 ст. 3). Судові рішення також можуть публікуватися в друкованих виданнях із додержанням вимог цього закону. Водночас, якщо судовий розгляд відбувався у закритому судовому засіданні, судове рішення оприлюднюється за винятком інформації, яка за рішенням суду щодо розгляду справи у закритому судовому засіданні підлягає захисту від розголошення.

Не тільки судове рішення, а й загальна інформація про судовий процес має бути доступною для учасників та зацікавлених осіб. Відповідно до ст. 11 Закону України «Про судоустрій і статус суддів» ${ }^{25}$ інформація про суд, який розглядає справу, сторони спору та предмет позову, дату надходження позовної заяви, апеляційної, касаційної скарги, заяви про перегляд судового рішення, стадії розгляду справи, місце, дату і час судового засідання, рух справи з одного суду до іншого є відкритою та має бути невідкладно оприлюдненою на офіційному веб-порталі судової влади України https://court.gov.ua. Яка саме інформація не підлягає оприлюдненню, передбачено частиною п'ятою ст. 8 ЦПК. Отже, складається ситуація, коли частина інформації про судовий розгляд справи $є$ доступною для всіх охочих, а частина - ні, з огляду на необхідність забезпечення права на приватне життя особи відповідно до положень цивільного законодавства України ${ }^{26}$.

У положеннях ЦПК в новій редакції від 03 жовтня 2017 р. принцип гласності та відкритості трансформувався у дві взаємодоповнюючі засади - принцип гласності судового процесу та принцип відкритості інформації щодо справи, передбачений ст. 8 ЦПК. Відповідно до частини першої ст. 8 ніхто не може бути позбавлений права на інформацію про дату, час і місце розгляду своєї справи або обмежений у праві отримання в суді усної або письмової інформації про результати розгляду його судової справи, а будь-яка особа, яка не є учасником справи, має право на доступ до судових рішень у порядку, встановленому законом.

Порядок оприлюднення інформації, визначеної законодавством, має бути врегульовано Положенням про Єдину судову інформаційно-телекомунікаційну систему, але проект зазначеного Положення було підготовлено і наразі за результатами обговорення Ради суддів направлено на доопрацювання 27.

Варто додати, що Законом України «Про інформацію», яким проголошено засади відкритості та доступності інформації, свобода обміну інформацією (ст. 2), а також закріплено право кожного на інформацію, що передбачає можливість вільного одержання, використання, поширення, зберігання та захисту інформації, необхідної для реалізації своїх прав, свобод і законних інтересів 28 . Водночас ч. 2 ст. 6 зазначеного Закону закріплено положення про те, що право на інформацію може бути обмежене законом в інтересах національної безпеки, територіальної цілісності або громадського порядку, з метою запобігання заворушенням чи злочинам, для охорони здоров'я населення, для захисту репутації або прав інших людей, для запобігання розголошенню інформації, одержаної конфіденційно, або для підтримання авторитету і неупередженості правосуддя (курсив автора).

Варто зауважити про контроверсійність зазначеного положення про необхідність обмеження права на інформацію з метою підтримання авторитету і неупередженості правосуддя. Виходячи з практики ЄСПЛ, можна допустити таке обмеження тільки за умов забезпечення інтересів здійснення правосуддя у справі 29. Відповідно відкритість та гласність правосуддя таким чином має обмежуватися інтересами здійснення правосуддя у конкретній справі, а також з метою реалізації його превентивної функції.

Після судове провадження, а саме виконання судового рішення, $є$ невід'ємною частиною процесу захисту прав, як ми вже зазначали, що зумовлює необхідність забезпечення гласності та відкритості. У ст. 2 нового Закону про виконання ${ }^{30}$ було закріплено гласність та відкритість як засади здійснення виконавчого провадження. У Законі України «Про органи та осіб, які здійснюють примусове виконання судових рішень і рішень інших органів» ${ }^{31}$ (далі - Закон про виконавців) серед принципів діяльності органів державної виконавчої служби та приватних виконавців закріплено гласність та відкритість виконавчого провадження та його фіксування технічними засобами.

3 комплексного тлумачення законодавства про виконавче провадження можна зробити висновки, що відкритість виконавчого процесу забезпечується наразі за допомогою запровадження і функціонування автоматизованої системи виконавчого провадження (далі - АСВП) ${ }^{32}$.

АСВП запроваджена в Україні відповідно до Положення про автоматизовану систему виконавчого провадження, затвердженого Наказом Міністерства юстиції України від 05 серпня 2016 р. № 2432/533 (далі Положення про АСВП). Вільний та безоплатний доступ до інформації АСВП забезпечує Міністерство юстиції України у мережі Інтернет на своєму офіційному веб-сайті https://asvpweb.minjust.gov.ua/\#/search-debtors 3 можливістю перегляду, пошуку, копіювання та роздрукування інформації, на основі поширених веб-оглядачів та редакторів, без необхідності застосування спеціально створених для цього технологічних та програмних засобів, без обмежень та цілодобово.

Стосовно об'єкта доступу, то у параграфі VI Положення про АСВП зауважується, що Міністерство юстиції України забезпечує вільний та безоплатний доступ до інформації АСВА з можливістю перегляду, пошуку, копіювання та роздрукування інформації (на основі поширених веб-оглядачів та редакторів) без обмежень та цілодобово у формі відкритих даних, а саме прізвище, ім'я, по батькові (за його наявності), число, місяць, рік народження боржника - фізичної особи та прізвище, ім'я, по батькові (за його наявності) стягувача - фізичної особи; найменування, ідентифікаційний код в Єдиному державному реєстрі юридичних 


\section{Студентська трибуна}

осіб, фізичних осіб - підприємців та громадських формувань для юридичної особи - боржника та стягувача; номер, дата відкриття та стан виконавчого провадження; найменування органу державної виконавчої служби (приватного виконавця), у якого перебуває на виконанні виконавче провадження.

Відповідно виходячи із загальних положень про публічність судового розгляду та виконання судового рішення, що реалізується в концепції права особи на справедливий суд, у вільному доступі має бути інформація щодо підстави відкриття виконавчого провадження у справі, зокрема, в межах даного наукового дослідження, це судове рішення у справі, на підставі якого здійснюється виконання. Така інформація $\epsilon$ доступною у ЄДРСР, що забезпечує будь-якій особі права на вільний доступ до всіх судових рішень відповідно до Закону України «Про доступ до судових рішень» ${ }^{34}$ на сайті http://reyestr.court.gov.ua.

Розміщення такої інформації у вільному доступі сприятиме підвищенню довіри до судової влади в України, підтверджуватиме цілісність та завершеність процесу судового розгляду у справі та виконання остаточних рішень національних судів, забезпечуючи реалізацію положень Європейської конвенції про право особи на справедливий суд та практики ЄСПЛ.

Варто виходити також 3 того, що рішення судів можуть торкатися прав та/або інтересів осіб, які не брали участі у справі та які мають право згідно із процесуальним законодавством України звернутися за оскарженням такого рішення у передбаченому законом порядку 35 . Відповідно для зазначених вище категорій осіб інформація щодо судового рішення, якщо стало підставою відкриття виконавчого провадження як об’єкт, що розміщується в АСВП, розміщений у вільному доступі, означає інтереси правосуддя.

Таким чином, доступ до АСВП, що надається тільки уповноваженим органам, а також тільки сторонам виконавчого провадження у справі, не відповідає загальним засадам відкритості інформації про захист прав осіб та здійснення правосуддя. Виходячи із засади забезпечення відкритого доступу до інформації про судові рішення, а також обмеженого доступу до матеріалів справи осіб, які не брали участі у справі за умови, що рішення торкається їх прав, а також враховуючи загальні засади необхідності публічного судового розгляду справи та виконання судового рішення, визначеного положеннями Європейської конвенції, необхідно передбачити різнорівневий доступ до інформації про виконавче провадження у справі у відкритому доступі, особам, які не брали участі в справі, тобто у вільному доступі, а також особам, які брали участь у справі, суду, що ухвалив рішення, яке підлягає виконанню.

Водночас з метою недопущення помилок під час внесення інформації, що підлягає оприлюдненню, а також недопущення можливих зловживань щодо внесення інформації для відкритого доступу, варто запровадити механізм перевірки та контролю інформації, що розмішується у вільному доступі в АСВП і передбачити право осіб, щодо яких розміщується така інформація, на перевірку такої інформації впродовж певного часу з моменту вирішення питання про ії розміщення за прикладом інституту перевірки інформації про судову справу, що підлягає оприлюдненню у ФП ЦП США

Згідно з правилом 79 ФП ЦП США матеріали цивільної справи зберігаються відповідно до встановлених у США правилах судовим клерком у вигляді так званих «civil docket» - це матеріали справи, що включаються і ведуться в відповідному реєстрі ${ }^{37}$, позначені послідовними номерами 3 першого запису в справі, включаючи: (a) документи, подані клерку; (b) видані у процесі з доказами вручення або іншого виконання; (c) виступи, накази, вироки та рішення. Інформація про справу, рішення та інші матеріали справи $є$ доступними публічно за винятком положень щодо персональних даних осіб, які брали в ній участь.

У США врегульовано положення щодо захисту інформації стосовно персональних даних учасників судових процесів, що збирається, зберігається та/або розповсюджується. Відповідно до змін до Апеляційних, цивільних та кримінальних правил щодо виконання вимог Закону про електронне урядування 2002 р., що вступили в дію 31 грудня 2007 p. ${ }^{38}$, суди, які готують електронні документи як дистанційно доступні для громадськості, повинні надати доступ адвокатам у справі переглянути їх щодо ідентифікаторів персональних даних, які відповідно до федеральних правил повинні бути відредаговані. Упродовж семи календарних днів 3 моменту вручення судовим репортером або переписувачем офіційної розшифровки до канцелярії кожен адвокат повинен повідомити суд, подавши повідомлення про редагування, про наміри керувати редагуванням щодо персональних даних з електронного протоколу судового розгляду. Якщо таке повідомлення не буде подане протягом призначеного часу, суд приймає рішення, що редагування ідентифікаторів персональних даних з розшифровки не є необхідним.

Варто зазначити, що наразі в чинному законодавстві України відсутні такі механізми, які дозволяють доступ до документів, що підлягають опублікуванню, зокрема, судові рішення у справі, що іноді приводить до порушень права особи на захист персональних даних ${ }^{39}$.

У висновку слід зауважити, що відкритість та гласність здійснення правосуддя закріплені в основних фундаментальних актах, що гарантують верховенство права та доступ до суду, а також у національному законодавстві про судоустрій та про судочинство, на жаль, не знайшли свого логічного продовження в Законі про виконання, зокрема, щодо гласності здійснення конкретних процесуальних дій та відкритості доступу до інформації про виконання судового рішення, що має кореспондуватися в цілому із загальними положеннями процесуальних кодексів та національного законодавства про судоустрій і статус суддів в Україні.

Конкретні елементи, що виступають гарантіями реалізації принципів гласності та відкритості, мають знайти відповідне відображення і в діяльності виконавців, з урахуванням ії̈ специфіки. Зокрема, як і участь публіки відповідно впливає на суспільну довіру до судів і сприяє превентивній меті здійснення правосуддя, відкритий доступ до інформації істотно спростить роботу виконавця та забезпечить більший рівень довіри 
до нього. Це полегшить здійснення правосуддя у загальному, оскільки заінтересовані особи обізнані в своїх правах за допомогою поширеної інформації про чинне законодавство, правила судочинства та виконання судових рішень, а також іншої, необхідної заявникові та іншим учасникам справи.

Водночас відкрита інформація про справу має бути підконтрольна сторонам провадження 3 метою недопущення порушень права на захист персональних даних, зокрема, за допомогою запровадження інституту перевірки судових рішень та інших документів, що підлягають оприлюдненню у встановленому законом порядку, адвокатами або їх уповноваженими представниками.

1 Загальна декларація про права людини. URL: http:/www.un.org.ua/ua/publikatsii-ta-zvity/global-un-publications/3722zahalna-deklaratsiia-prav-liudyny

2 Конвенція про захист прав людини та основоположних свобод. URL: https://zakon.rada.gov.ua/laws/show/995_004

3 У нашій статті, зокрема, проаналізовано Федеральні правила цивільного процесу Сполучених Штатів Америки (далі ФП ЦП США), а також Правил цивільного процесу Англії та Уельсу (далі - ПЦП АУ) з огляду на необхідність вивчення світового досвіду реалізації положень про публічність захисту прав та виконання судових рішень.

4 Див.: Цивільний процесуальний кодекс України. URL: https://zakon.rada.gov.ua/laws/show/1618-15/print; Господарський процесуальний кодекс України. URL: https://zakon.rada.gov.ua/laws/show/1798-12/print (далі - ГПК); Кодекс адміністративного судочинства України. URL: https://zakon.rada.gov.ua/laws/show/2747-15/print (далі - КАC).

5 Про виконавче провадження : Закон України. URL: https://zakon.rada.gov.ua/laws/show/1404-19/print

6 Див.: Снідевич С.О. Гласність як засада побудови виконавчої процесуальної форми. Актуальні проблеми вітчизняної юриспруденції. Спецвипуск. 2019. С. 72-75. URL: http://apnl.dnu.in.ua/2019/21.pdf

7 Загальна декларація про права людини. URL: http://www.un.org.ua/ua/publikatsii-ta-zvity/global-un-publications/3722zahalna-deklaratsiia-prav-liudyny

${ }^{8}$ В сучасній українській науці про принцип публічності в цивільному судочинстві див. детальніше: Кройтор В.А. Гласність як одна з основних засад цивільного. Південноукраӥнський правничий часопис. 2008. № 2. С. 64-66; Проблеми теорії та практики цивільного судочинства: монографія / Комаров В.В. та ін.; за заг. ред. В.В. Комарова. Харків: Харків юридичний, 2008. 928 с. С. 61; Ізарова І.О. Принцип публічності в цивільному процесі і його зміст. Вісник Київського національного університету імені Тараса Шевченка. Юридичні науки. 2011. № 89. С. 66-69 та ін.

9 Щодо публічності правосуддя як елементу верховенства права, див. детальніше Cappelletti M. Social and Political Aspects of Civil Procedure-Reforms and Trends in Western and Eastern Europe. 69 Mich. L. Rev. 847 (1970-1971). Pp. 847-861; Jolowicz J. Adversarial and Inquisitorial Models of Civil Procedure. International and Comparative Law Quarterly. No 52 (2). 2003. URL: https://doi.org/10.1093/iclq/52.2.281; Hazzard G.G.Jr. Social Justice Through Civil Justice. 26 University Chicago Law Review. No 36. 1968-1969. Рр. 699 та ін.

10 Конвенція про захист прав людини та основоположних свобод. URL: https://zakon.rada.gov.ua/laws/show/995_004

11 Див. також: Recommendation $\operatorname{Rec}(2003) 17$ of the Committee of Ministers to member states on enforcement (adopted by the Committee of Ministers on 9 September 2003 at the $851^{\text {st }}$ meeting of the Ministers' Deputies. URL: https://search.coe.int/cm/Pages/ result_details.aspx?ObjectId $=09000016805 \mathrm{df0c} 1$ The Guidelines for a better implementation of the existing Council of Europe recommendation on enforcement (CEPEJ(2009), 11REV2, 17 December 2009, adopted by the CEPEJ at its 14th plenary meeting, in Strasbourg, on 9 and 10 December 2009. URL: https://rm.coe.int/16807473cd

12 Рішення ЄСПЛ у справі Крутько проти України від 27 листопада 2008 p. URL: https://zakon.rada.gov.ua/go/974_422

13 Рішення ССПЛ у справі Шмалько проти України від 20 липня 2004 p. URL: https://zakon.rada.gov.ua/go/980_226. Вперше Суд про це зазначив в своєму історичному рішенні у справи Hornsby v. Greece від 19 березня 1997 p.

14 Див. рішення ЄСПЛ у справі Ромашов проти України від 27 липня 2004 p. URL: https://zakon.rada.gov.ua/go/980_227, а також рішення ЄСПЛ у справі Дубенко проти України від 11 січня 2005 p. URL: https://zakon.rada.gov.ua/go/980_251

15 Див. також: Виконавче провадження / автор. колектив, під ред. В.В. Комарова. Харків, Право, 2014. 717 с.

16 Див. також: Recommendation Rec(2003)17 of the Committee of Ministers to member states on enforcement (adopted by the Committee of Ministers on 9 September 2003 at the $851^{\text {st }}$ meeting of the Ministers' Deputies. URL: https://search.coe.int/cm/Pages/ result_details.aspx?ObjectId $=09000016805 \mathrm{df0} 1$ The Guidelines for a better implementation of the existing Council of Europe recommendation on enforcement (CEPEJ(2009), 11REV2, 17 December 2009, adopted by the CEPEJ at its 14th plenary meeting, in Strasbourg, on 9 and 10 December 2009. URL: https://rm.coe.int/16807473cd

17 Конституція України. URL: https://zakon.rada.gov.ua/laws/show/254к/96-вр

18 Рішення Конституційного Суду України у справі за конституційним зверненням товариства з обмеженою відповідальністю «Пріма-Сервіс» ЛТД щодо офіційного тлумачення положення пункту 7 частини третьої статті 129 Конституції України та за конституційним поданням 54 народних депутатів України щодо відповідності Конституції України (конституційності) окремих положень частини шостої статті 12, частини першої статті 41 Кодексу адміністративного судочинства України, частини другої статті 197 Цивільного процесуального кодексу України, а також частини восьмої статті 81-1 Господарського процесуального кодексу України (справа про фіксування судового процесу технічними засобами). URL: https://zakon.rada.gov.ua/ laws/show/v016p710-11

19 Цивільний процесуальний кодекс. URL: https://zakon.rada.gov.ua/laws/show/1618-15/print

20 Господарський процесуальний кодекс. URL: https://zakon.rada.gov.ua/laws/show/1798-12/print

21 Кодекс адміністративного судочинства України. URL: https://zakon.rada.gov.ua/laws/show/2747-15/print

22 Про судоустрій і статус суддів: Закон України. URL: https://zakon.rada.gov.ua/laws/show/1402-19

23 Про доступ до судових рішень: Закон України. URL: https://zakon.rada.gov.ua/go/3262-15

24 Див. детальніше статтю одного із експертів Центру політико-правових реформ - авторів зазначеного проекту закону: Лесюк Т. Діяльність судової влади стане прозорішою. Юридична газета. 2005. № 1(61). С. 5.

25 Про судоустрій і статус суддів: Закон України. URL: https://zakon.rada.gov.ua/laws/show/1402-19

26 Цивільний кодекс України. URL: https://zakon.rada.gov.ua/go/435-15

27 Див. детальніше: Рада суддів України затвердила консультативний висновок про Єдину судову інформаційно-телекомунікаційну систему. URL: http://rsu.gov.ua/en/news/rada-suddiv-ukraini-zatverdila-konsultativnij-visnovok-pro-edinu-sudovuinformacijno-telekomunikacijnu-sistemu 


\section{Студентська трибуна}

28 Про інформацію: Закон України. URL: https://zakon.rada.gov.ua/go/2657-12

29 Див. для прикладу положення п. g ч. 3 правила 39.2 Правил цивільного процесу Англії та Уельсу (The Civil Procedure Rules 1998. URL: http://www.justice.gov.uk/courts/procedure-rules/civil/rules)

30 Про виконавче провадження: Закон України. URL: https://zakon.rada.gov.ua/laws/show/1404-19/print

31 Про органи та осіб, які здійснюють примусове виконання судових рішень і рішень інших органів: Закон України. URL: https://zakon.rada.gov.ua/laws/show/1403-19/print

32 Див.: Снідевич С.О. Гласність як засада побудови виконавчої процесуальної форми. Актуальні проблеми вітчизняної юриспруденціï. Спецвипуск. 2019. С. 72-75. URL: http://apnl.dnu.in.ua/2019/21.pdf

33 Положення про автоматизовану систему виконавчого провадження, затв. наказом Міністерства юстиції України від 05 серпня 2016 р. № 2432/5. URL: https://zakon.rada.gov.ua/laws/show/z1126-16/ed20180828

34 Про доступ до судових рішень: Закон України. URL: https://zakon.rada.gov.ua/go/3262-15

35 Див. частину другу ст. 8 ЦПК, відповідно до якої особи, які не брали участі у справі, якщо суд вирішив питання про їхні права, свободи, інтереси та (або) обов'язки, які подали апеляційну чи касаційну скаргу на відповідне рішення, мають право ознайомлюватися з матеріалами справи, робити з них витяги, знімати копії з документів, долучених до справи, одержувати копії судових рішень; а також частину першу ст.17 ЦПК, згідно з якою особи, які не брали участі у справі, якщо суд вирішив питання про їхні права, свободи, інтереси та (або) обов'язки, мають право на апеляційний перегляд справи та у визначених законом випадках - на касаційне оскарження судового рішення; і частину першу ст. 352 щодо права осіб, які не брали участі у справі, якщо суд вирішив питання про їхні права, свободи, інтереси та (або) обов'язки, на оскарження в апеляційному порядку рішення суду першої інстанції повністю або частково.

36 Federal Rules of Civil Procedure, eff. Dec. 1, 2018. URL: https://www.uscourts.gov/rules-policies/current-rules-practice-pro cedure/federal-rules-civil-procedure

37 Див. детальніше на сторінці Court Records. URL: https://www.uscourts.gov/court-records

38 Privacy Policy for Electronic Case Files. URL: https://www.uscourts.gov/rules-policies/judiciary-policies/privacy-policy-elect ronic-case-files

39 Див.: Захист персональних даних: правове регулювання та практичні аспекти: практ. посіб. URL: https://rm.coe.int/ $168059920 \mathrm{c}$

References:

Cappelletti, M. (1970-1971) Social and Political Aspects of Civil Procedure-Reforms and Trends in Western and Eastern Europe. 69 Mich. L. Rev. 847. 847-861 [in English].

Court Records. URL: https://www.uscourts.gov/court-records [in English].

Federal Rules of Civil Procedure, eff. Dec. 1, 2018. URL: https://www.uscourts.gov/rules-policies/current-rules-practice-proce dure/federal-rules-civil-procedure [in English].

Hazzard, G. G. Jr. (1968-1969) Social Justice Through Civil Justice. 26 University Chicago Law Review. 36,699 [in English]. Hospodarskyi protsesualnyi kodeks Ukrainy. URL: https://zakon.rada.gov.ua/laws/show/1798-12/print [in Ukrainian].

Izarova, I. O. (2011) Pryntsyp publichnosti v tsyvilnomu protsesi i yoho zmist. Visnyk Kyivskoho natsionalnoho universytetu imeni Tarasa Shevchenka. Yurydychni nauky. 89, 66-69 [in Ukrainian].

Jolowicz, J. (2003) Adversarial and Inquisitorial Models of Civil Procedure. International and Comparative Law Quarterly. 52(2).

URL: https://doi.org/10.1093/iclq/52.2.281

Kodeks administratyvnoho sudochynstva Ukrainy. URL: https://zakon.rada.gov.ua/laws/show/2747-15/print

Konventsiia pro zakhyst prav liudyny ta osnovopolozhnykh svobod. URL: https://zakon.rada.gov.ua/laws/show/995_004 [in Ukrainian].

Kroitor, V. A. (2008) Hlasnist yak odna z osnovnykh zasad tsyvilnoho sudochynstva. Pivdennoukrainskyi pravnychyi chasopys. 2, 64-66 [in Ukrainian].

Lesiuk, T. (2005) Diialnist sudovoi vlady stane prozorishoiu. Yurydychna hazeta. 1(61), 5 [in Ukrainian].

Polozhennia pro avtomatyzovanu systemu vykonavchoho provadzhennia, zatv. Nakazom Ministerstva yustytsii Ukrainy 05 serpnia 2016 № 2432/5. URL: https://zakon.rada.gov.ua/laws/show/z1126-16/ed20180828 [in Ukrainian].

Privacy Policy for Electronic Case Files. URL: https://www.uscourts.gov/rules-policies/judiciary-policies/privacy-policy-elec tronic-case-files [in English].

Komarov, V. V. (za zah. red.). (2008). Problemy teorii ta praktyky tsyvilnoho sudochynstva. Kharkiv: Kharkiv yurydychnyi [in Ukrainian].

Rada suddiv Ukrainy zatverdyla konsultatyvnyi vysnovok pro Yedynu sudovu informatsiino-telekomunikatsiinu systemu. URL: http://rsu.gov.ua/en/news/rada-suddiv-ukraini-zatverdila-konsultativnij-visnovok-pro-edinu-sudovu-informacijno-telekomunika cijnu-sistemu [in Ukrainian].

Recommendation Rec (2003)17 of the Committee of Ministers to member states on enforcement (adopted by the Committee of Ministers on 9 September 2003 at the 851st meeting of the Ministers Deputies. URL: https://search.coe.int/cm/Pages/result_details. aspx?ObjectId=09000016805df0c1 [in English].

Rishennia Konstytutsiinoho Sudu Ukrainy u spravi za konstytutsiinym zvernenniam tovarystva z obmezhenoiu vidpovidalnistiu "Prima-Servis" LTD shchodo ofitsiinoho tlumachennia polozhennia punktu 7 chastyny tretoi statti 129 Konstytutsii Ukrainy ta za konstytutsiinym podanniam 54 narodnykh deputativ Ukrainy shchodo vidpovidnosti Konstytutsii Ukrainy (konstytutsiinosti) okremykh polozhen chastyny shostoi statti 12, chastyny pershoi statti 41 Kodeksu administratyvnoho sudochynstva Ukrainy, chastyny druhoi statti 197 Tsyvilnoho protsesualnoho kodeksu Ukrainy, a takozh chastyny vosmoi statti 81-1 Hospodarskoho protsesualnoho kodeksu Ukrainy (sprava pro fiksuvannia sudovoho protsesu tekhnichnymy zasobamy). URL: https://zakon.rada.gov.ua/laws/show/v016p710-11 [in Ukrainian].

Rishennia YeSPL u spravi Dubenko proty Ukrainy vid 11 sichnia 2005 r. URL: https://zakon.rada.gov.ua/go/980 251 [in Ukrainian]. Rishennia YeSPL u spravi Krutko proty Ukrainy vid 27 lystopada 2008 r. URL: https://zakon.rada.gov.ua/go/974_422 [in Ukrainian].

Rishennia YeSPL u spravi Romashov proty Ukrainy vid 27 lypnia 2004 r. URL: https://zakon.rada.gov.ua/go/980_227 [in Ukrainian].

Rishennia YeSPL u spravi Shmalko proty Ukrainy vid 20 lypnia 2004 r. URL: https://zakon.rada.gov.ua/go/980_226 [in Ukrainian].

Snidevych, S. O. (2019) Hlasnist yak zasada pobudovy vykonavchoi protsesualnoi formy. Aktualni problemy vitchyznianoi yurysprudentsii. Spetsvypusk, 72-75. URL: http://apnl.dnu.in.ua/2019/21.pdf [in Ukrainian]. 
The Civil Procedure Rules 1998 http://www.justice.gov.uk/courts/procedure-rules/civil/rules [in Ukrainian].

The Guidelines for a better implementation of the existing Council of Europe recommendation on enforcement (CEPEJ(2009), 11REV2, 17 December 2009, adopted by the CEPEJ at its 14th plenary meeting, in Strasbourg, on 9 and 10 December 2009. URL: https://rm.coe.int/16807473cd [in Ukrainian].

Tsyvilnyi kodeks Ukrainy. URL: https://zakon.rada.gov.ua/go/435-15 [in Ukrainian].

Tsyvilnyi protsesualnyi kodeks Ukrainy. URL: https://zakon.rada.gov.ua/laws/show/1618-15/print [in Ukrainian].

Komarova, V.V. (red.). (2014) Vykonavche provadzhennia. Kharkiv, Pravo [in Ukrainian].

Zahalna deklaratsiia pro prava liudyny. URL: http://www.un.org.ua/ua/publikatsii-ta-zvity/global-un-publications/3722-zahalnadeklaratsiia-prav-liudyny [in Ukrainian].

Zakhyst personalnykh danykh: pravove rehuliuvannia ta praktychni aspekty. Praktychnyi posibnyk. URL: https://rm.coe.int/ 168059920 c [in Ukrainian].

Zakon Ukrainy «Pro dostup do sudovykh rishen». URL: https://zakon.rada.gov.ua/go/3262-15 [in Ukrainian].

Zakon Ukrainy «Pro informatsiiu». URL: https://zakon.rada.gov.ua/go/2657-12 [in Ukrainian].

Zakon Ukrainy «Pro orhany ta osib, yaki zdiisniuiut prymusove vykonannia sudovykh rishen i rishen inshykh orhaniv».

URL: https://zakon.rada.gov.ua/laws/show/1403-19/print [in Ukrainian].

Zakon Ukrainy «Pro sudoustrii i status suddiv». URL: https://zakon.rada.gov.ua/laws/show/1402-19 [in Ukrainian].

Zakon Ukrainy «Pro vykonavche provadzhennia». URL: https://zakon.rada.gov.ua/laws/show/1404-19/print [in Ukrainian].

\section{Резюме} людини.

Турканова В.І. Відкрите і гласне виконання судових рішень в Україні в світлі практики Європейського суду з прав

У статті розкривається правова природа принципу гласності та відкритості виконавчого процесу на основі дослідження національного законодавства та законодавства інших держав, положень правової доктрини й судової практики, а також практики ЄСПЛ. Принцип гласності та відкритості виконавчого процесу охарактеризовано в світлі забезпечення доступності правосуддя та права на справедливий судовий розгляд. Також проведено аналіз законодавства США, Англії та Уельсу, права ЄС та запропоновано вирішення проблеми доступу до відкритої інформації про судову справу та персональних даних ії учасників. У результаті проведеного дослідження у роботі були запропоновані зміни до національного законодавства, що покликані забезпечити доступ до інформації під час виконання судових рішень та гарантувати право на ефективний засіб правового захисту.

Ключові слова: виконання судових рішень, доступ до правосуддя, відкритість правосуддя, цивільний процес.

Резюме

Турканова В.И. Открытое и гласное исполнение судебных решений в Украине в свете практики Европейского суда по правам человека.

В статье раскрывается правовая природа принципа гласности и открытости исполнительного процесса на основе исследования национального законодательства и законодательства других государств, положений правовой доктрины и судебной практики, а также практики ЕСПЧ. Принцип гласности и открытости исполнительного процесса охарактеризован в свете обеспечения доступности правосудия и правая на справедливое судебное разбирательство. Также проведен анализ законодательства США, Англии и Уэльса, права ЕС и предложено решения проблемы доступа к открытой информации о судебном деле и персональных данных ее участниках. В результате проведенного исследования в работе были предложены изменения в национальное законодательство, которые призваны обеспечить доступ к информации во время выполнения судебных решений и гарантировать право на эффективное средство правовой защиты.

Ключевые слова: исполнение судебных решений, доступ к правосудию, открытость правосудия, гражданский процесс.

\section{Summary}

Vladyslava Turkanova. Open Enforcement in Ukraine Within the European Court of Human Right’s Practice.

Publicity and openness of the trial are inherent features of justice, providing the opportunity for public involvement and an appropriate level of credibility, as well as guaranteeing the implementation of other principles of justice, such as the equality of parties and their competitiveness.

During the reform of the judiciary in Ukraine, the various procedural codes of Ukraine substantially updated in according the provisions on openness and publicity of court proceedings. In particular, the new wording of the Civil Procedural Code of Ukraine the publicity of the trial and the openness of information about the case were clarified, in particular, Articles 7 "Publicity of the trial" and 8 "Openness of information about the case". A new Law on Enforcement Proceedings was also enacted and in its Article 2 of the principles of enforcement proceedings were laid down, including the publicity and openness of enforcement proceedings in Ukraine. At the same time, there are no any specific provisions of this principle disclosed in the said law. Therefore, this paper is related to the legal nature of the public principle of justice, in particular, oral hearing and openness of the information concerning enforcement of judicial decisions.

The main grounds for this study are the national legislation of Ukraine and the legislation of other states, in particular, Federal Rules of Civil Procedure of the USA, Civil Procedure Rules of England and Wales, acquis of the EU, CE Recommendations and Guidelines as well as the legal doctrine and judicial practice, including the practice of the ECHR.

It was concluded, that the principle of publicity should be characterized in the light of ensuring the access of justice and the right to a fair trial, mentioned in European Convention and realized in ECHR practice. The laws of the United States were carried out, and a solution for the problem of data rights was proposed. As a result of the study, changes in national legislation were proposed to ensure access to information during the enforcement of court decisions and to guarantee the right to an effective remedy.

Key words: enforcement of judicial decisions, access to justice, open justice, civil procedure. 